\title{
Evaluation of Physico-Chemical and Microbiological Quality of Milk of Banaskantha District, India
}

\author{
S.B. Nalwaya ${ }^{1}$, B.I. Prajapati ${ }^{2 *}$, A.R. Bariya ${ }^{3}$, M.M. Goswami ${ }^{1}$ and S.K. Roy ${ }^{1}$ \\ ${ }^{1}$ Department of Livestock Products Technology, ${ }^{2}$ Department of Veterinary Public Health and \\ Epidemiology, College of Veterinary Science and Animal Husbandry, S.D.A.U., \\ Sardarkrushinagar, Gujarat, India \\ ${ }^{3}$ Department of Livestock Products Technology, College of Veterinary Science and Animal \\ Husbandry, Junagadh Agricultural University, Junagadh-362001, Gujarat, India \\ *Corresponding author
}

\section{A B S T R A C T}

\section{Keywords}

Milk, Physicochemical quality, Microbiological quality, Standard plate count

\section{Article Info}

Accepted:

12 November 2018 Available Online:

10 December 2018
The quality of milk in selective areas (Dantiwada, Deesa, Palanpur, Panthawada and Tharad) of Banaskantha district (Gujarat) was analysed for physico-chemical and microbiological quality. The average fat content (per cent), acidity (per cent LA), moisture and $\mathrm{pH}$ of milk samples were found in the range of $4.81 \pm 0.18$ to $6.02 \pm 0.13,0.14$ to 0.16 (per cent LA), $85.64 \pm 0.29$ to $88.4 \pm 0.82,6.36 \pm 0.04$ to $6.55 \pm 0.05$, respectively. Mean values of fat content and acidity of milk samples showed significant $(\mathrm{P}<0.05)$ variation while there is no significance difference was observed in moisture content and $\mathrm{pH}$ of milk samples among all selected places of Banaskantha district. SPC and Coliform count for milk samples were $6.10 \pm 0.03,6.00 \pm 0.01,5.97 \pm 0.01,6.12 \pm 0.03$ and $6.21 \pm 0.04(\log \mathrm{cfu} / \mathrm{ml})$ and $3.66 \pm 0.04,3.42 \pm 0.04,3.23 \pm 0.04,3.49 \pm 0.06$ and $3.54 \pm 0.04(\log \mathrm{cfu} / \mathrm{ml})$, respectively. The lowest SPC count $(5.97 \pm 0.01 \mathrm{log} \mathrm{cfu} / \mathrm{ml})$ and coliform count $(3.23 \pm 0.04 \mathrm{log} \mathrm{cfu} / \mathrm{ml})$ were observed in milk samples of Palanpur. Yeast and mould count was not at all observed in any of analysed milk samples of Banaskantha district. A comprehensive research work is required to set a standard for commercial production of raw milk and milk products as regard to Gujarat in turn at all India level.

\section{Introduction}

India continues to be the largest producer of milk in world by producing 155.5 million tonnes in 2015-16 showing an annual growth of $6.27 \%$. The per capita availability of milk in our country is $337 \mathrm{~g}$ whereas at world level it is $299 \mathrm{~g}$ per day in the year 2015-16 (Annual report, 2016-17, DAHD\&F, GoI). This represents a sustainable growth in availability of milk and milk products for the ever increasing population. Dairying is in many ways the number one income for millions of rural households engaged in agriculture.

Gujarat is the $3^{\text {rd }}$ largest milk producing state (12.3 million tonnes) in India contributing about 8.0 per cent of the total milk production 
of the country. Milk production density is 58.6 tonnes/square $\mathrm{km}$ in an area of about 11691 million square kilometers. It has $563 \mathrm{~g} /$ day per-capita availability which is more than the national average. In Banaskantha district, the total milk production is around 1.204 million tonnes. This district contributes 13.19 per cent to the state.

Indian mythology as well as in its traditional medical practices, milk act as rejuvenator, has health protecting and promoting properties, hence can be referred as one of the best vitalisers and it is considered the most important part of our diet.

But the greatest drawback is its initial quality which results in its poor shelf life. Numerous factors are responsible, some of the most important causes are: health of the animal, housing, sanitation along with the person involved in the production, their health, sanitary practices followed by them and finally the container in which milk is poured which is invariably contaminating and last but not the least tropical nature of climate of our country. All of these immediately affect the quality of milk. Microbiologically, it is the poorest which results in marketing problem specially in western countries where the microbiological quality of milk should be as per FSSAI/CODEX and as a result the milk cannot be marketed to the western world. The problem is serving the worst when it comes to unorganized sector.

In the manner role the indigenous milk products where it has playing a pivotal role in our social, economics, religious and nutritional aspectand conversely poor quality. The main reason again is poor raw material, unhygienic human involvement, packing is not available in unorganized sector as compared to organized sector where finally continuous technology is used when human involvement is zero.
So, the chief concern is how to overcome all these problems, so as to take corrective measure to rectify and in turn boost up the economics of the country. To address all this; A basic work has to be carried out in the survey i.e. collection of milk and milk products (not packaged and not from organized sector) from the market followed by detail analysis. Based from the result, recommendation and corrective measure may be spell out.

The present study i.e. "Evaluation of physicochemical and microbiological quality of milk and milk products of Banaskantha district" is a small endeavor in this direction, where in selective places of Banaskantha district of Gujarat is taken which are as follow: Dantiwada, Deesa, Palanpur, Panthawada, Tharad. Based upon the facts and figure mentioned above, the objectives of the present study were collection of milk from different places of Banaskantha district, determination of physico-chemical properties of milk and assessing the microbiological quality of milk.

\section{Materials and Methods}

\section{Sample collection}

Milk samples were aseptically collected from vendor, shop, private dairies obtained from in market of Banaskantha district (Palanpur, Deesa, Panthawada, Dantiwada and Tharad) in the sterile bottles and transferred to laboratory on ice for further study. Samples were brought to the laboratory within three to four hours after collection.

\section{Physico-chemical analysis}

Physico-chemical analysis included the estimation of fat, titrable acidity, moisture content and $\mathrm{pH}$. Estimation of fat, titrable acidity and moisture content were estimated as perIS: 1224, 1977 and FSSAI section: 1.3.4, 
2015, IS:11623, 2008 and FSSAI, 2015,IS: 11766, 1986 and FSSAI, 2015, respectively while For determination of $\mathrm{pH}$, digital $\mathrm{pH}$ meter was used.

\section{Microbiological analysis}

The microbiological examination of milk was carried out by estimation of standard plate count, coliform count and yeast and mould count as per AOAC, 2016.

\section{Statistical analysis}

The results were statistically analysed as per the methods described by Snedecor and Cochran (1989). One-way analysis of variance (ANOVA) was conducted to analyse the results of physicochemical and microbiological properties of milk of Banaskantha District by using analytical software Sigmastat 4.0.

\section{Results and Discussion}

Considering the importance of milk in human diet, different samples were collected in selected places to assess the physico-chemical and microbiological qualities of milk sold in the unorganised sector of Banaskantha district, Gujarat. The results obtained were analysed using appropriate statistical method and presented as follows:

\section{Physicochemical analysis}

The average fat content (per cent), acidity (per cent LA), moisture and $\mathrm{pH}$ of milk samples sold in Dantiwada, Deesa, Palanpur, Panthawada and Tharad, places of Banaskantha district, Gujarat is presented in Table 1.

The fat content (per cent), acidity (per cent LA), moisture (per cent) and $\mathrm{pH}$ of milk samples collected from Dantiwada, Deesa, Palanpur, Panthawada and Tharad were
$5.80 \pm 0.27,4.81 \pm 0.18,6.02 \pm 0.13,5.67 \pm$ 0.19 and $5.56 \pm 0.25 ; 0.16 \pm 0.005,0.14 \pm 0.006$, $0.15 \pm 0.005, \quad 0.14 \pm 0.005$ and $0.15 \pm 0.004$; $88.41 \pm 0.82, \quad 88.20 \pm 0.79, \quad 86.54 \pm 0.49$, $85.64 \pm 0.2$ and $86.44 \pm 0.8$; and $6.55 \pm 0.05$, $6.38 \pm 0.05, \quad 6.46 \pm 0.07, \quad 6.36 \pm 0.04 \quad$ and $6.37 \pm 0.06$, respectively.

Mean values of fat content of milk samples showed significant $(\mathrm{P}<0.05)$ variation among the samples from Palanpur and Deesa; Dantiwada and Deesa, whereas rest of places showed no significant difference $(\mathrm{P}<0.05)$. The maximum fat $(6.02$ per cent $)$ was observed in the Palanpur. According to fat content, the samples could be placed as Palanpur $>$ Dantiwada $>$ Panthawada $>$ Tharad $>$ D eesa in descending order.

Acidity in milk have been measured in terms of per cent lactic acid, in different samples of milk is ranged from 0.14 to 0.16 (per cent LA). The highest acidity was observed in milk samples of Dantiwada ( 0.16 per cent LA) and lowest in milk samples from Deesa (0.14 per cent LA).

Acidity of milk samples showed significant variation $(P<0.05)$ between Dantiwada and Deesa; Panthawada and Dantiwada.

The moisture content of milk samples were in the range from $85.64 \pm 0.29$ per cent to $88.4 \pm 0.82$ per cent. Result indicated that no significant difference $(\mathrm{P}<0.05)$ was found among all selected places of Banaskantha district.

The mean values of $\mathrm{pH}$ in milk sample ranged from $6.36 \pm 0.04$ to $6.55 \pm 0.05$. All the places showed no significant difference $(\mathrm{P}<0.05)$.

\section{Microbiological analysis}

Standard plate count (SPC) of milk sample was studied with a view to know the number or total bio-load of the samples of milk. 
The results of SPC $(\log \mathrm{cfu} / \mathrm{ml})$, Coliform count $(\log \mathrm{cfu} / \mathrm{ml})$ and Yeast and mould count (log $\mathrm{cfu} / \mathrm{ml})$ for milk samples from five selected places of Banaskantha district (Dantiwada, Deesa, Palanpur, Panthawada and Tharad) depicted in Table 2.

SPC and Coliform count for milk samples were $6.10 \pm 0.03, \quad 6.00 \pm 0.01, \quad 5.97 \pm 0.01$, $6.12 \pm 0.03$ and $6.21 \pm 0.04(\log \mathrm{cfu} / \mathrm{ml})$ and $3.66 \pm 0.04,3.42 \pm 0.04,3.23 \pm 0.04,3.49 \pm 0.06$ and $3.54 \pm 0.04(\log \mathrm{cfu} / \mathrm{ml})$, respectively. The highest SPC was observed in milk samples of Tharad $(6.21 \pm 0.04 \log \mathrm{cfu} / \mathrm{ml})$ and lowest in milk samples of Palanpur $(5.97 \pm 0.01 \mathrm{log}$ $\mathrm{cfu} / \mathrm{ml})$. From Table 2, it is revealed that the SPC found in Tharad and Palanpur; Tharad and Deesa; Panthawada and Palanpur; Dantiwada and Palanpur varied significantly $(\mathrm{P}<0.05)$.

The highest coliform count was observed in milk sample of Dantiwada (3.66 \pm 0.04 log $\mathrm{cfu} / \mathrm{ml}$ ) and lowest in milk samples of Palanpur (3.23 $\pm 0.04 \log \mathrm{cfu} / \mathrm{ml})$. Mean values of coliform count content in milk samples shown significant $(\mathrm{P}<0.05)$ variation between Dantiwada and Palanpur; Tharad and Palanpur; Panthawada and Palanpur; Deesa and Dantiwada.

Yeast and mould count was not at all observed in any of analysed milk samples of Banaskantha district.

Table.1 Physico-chemical properties of milk samples in selective places of Banaskantha district

\begin{tabular}{|l|c|c|c|c|c|}
\hline $\begin{array}{l}\text { Places/ } \\
\text { Parameter }\end{array}$ & $\begin{array}{c}\text { Dantiwada } \\
(n=8) \\
\text { Mean } \pm \text { SE }\end{array}$ & $\begin{array}{c}\text { Deesa } \\
(n=8) \\
\text { Mean } \pm \text { SE }\end{array}$ & $\begin{array}{c}\text { Palanpur } \\
(n=8) \\
\text { Mean } \pm \text { SE }\end{array}$ & $\begin{array}{c}\text { Panthawada } \\
(n=8) \\
\text { Mean } \pm \text { SE }\end{array}$ & $\begin{array}{c}\text { Tharad } \\
(n=8) \\
\text { Mean } \pm \text { SE }\end{array}$ \\
\hline Fat (\%) & $5.80 \pm 0.27^{\mathrm{a}}$ & $4.81 \pm 0.18^{\mathrm{b}}$ & $6.02 \pm 0.13^{\mathrm{a}}$ & $5.67 \pm 0.19^{\mathrm{ab}}$ & $5.56 \pm 0.25^{\mathrm{ab}}$ \\
\hline Acidity (\% LA) & $0.16 \pm 0.005^{\mathrm{a}}$ & $0.14 \pm 0.006^{\mathrm{b}}$ & $0.15 \pm 0.005^{\mathrm{ab}}$ & $0.14 \pm 0.005^{\mathrm{b}}$ & $0.15 \pm 0.004^{\mathrm{ab}}$ \\
\hline Moisture (\%) & $88.41 \pm 0.82^{\mathrm{a}}$ & $88.20 \pm 0.79^{\mathrm{a}}$ & $86.54 \pm 0.49^{\mathrm{a}}$ & $85.64 \pm 0.29^{\mathrm{a}}$ & $86.44 \pm 0.8^{\mathrm{a}}$ \\
\hline $\mathrm{pH}$ & $6.55 \pm 0.05^{\mathrm{a}}$ & $6.38 \pm 0.05^{\mathrm{a}}$ & $6.46 \pm 0.07^{\mathrm{a}}$ & $6.36 \pm 0.04^{\mathrm{a}}$ & $6.37 \pm 0.06^{\mathrm{a}}$ \\
\hline
\end{tabular}

$*$ Mean \pm S.E of five replications within a row followed by the different letter are significantly different at $\mathrm{p}<0.05$

Table.2 Microbiological analysis $(\log \mathrm{cfu} / \mathrm{ml})$ of milk sample of selected places of Banaskantha District

\begin{tabular}{|l|c|c|c|c|c|}
\hline $\begin{array}{l}\text { Places/ } \\
\text { Parameter }\end{array}$ & $\begin{array}{c}\text { Dantiwada } \\
(n=8) \\
\text { Mean } \pm \text { SE }\end{array}$ & $\begin{array}{c}\text { Deesa } \\
(n=8) \\
\text { Mean } \pm \text { SE }\end{array}$ & $\begin{array}{c}\text { Palanpur } \\
(n=8) \\
\text { Mean } \pm \text { SE }\end{array}$ & $\begin{array}{c}\text { Panthawada } \\
(n=8) \\
\text { Mean } \pm \text { SE }\end{array}$ & $\begin{array}{c}\text { Tharad } \\
(n=8) \\
\text { Mean } \pm \text { SE }\end{array}$ \\
\hline SPC $(\log \mathrm{cfu} / \mathrm{ml})$ & $6.10 \pm 0.03^{\mathrm{a}}$ & $6.00 \pm 0.01^{\mathrm{ac}}$ & $5.97 \pm 0.01^{\mathrm{a}}$ & $6.12 \pm 0.03^{\mathrm{b}}$ & $6.21 \pm 0.04^{\mathrm{b}}$ \\
\hline $\begin{array}{l}\text { Coliform count } \\
(\log \mathrm{cfu} / \mathrm{ml})\end{array}$ & $3.66 \pm 0.04^{\mathrm{a}}$ & $3.42 \pm 0.04^{\mathrm{b}}$ & $3.23 \pm 0.04^{\mathrm{bc}}$ & $3.49 \pm 0.06^{\mathrm{ab}}$ & $3.54 \pm 0.04^{\mathrm{ab}}$ \\
\hline $\begin{array}{l}\text { Yeast and mould } \\
\text { count } \\
(\log \mathrm{cfu} / \mathrm{ml})\end{array}$ & Nil & Nil & Nil & Nil & Nil \\
\hline
\end{tabular}

$*$ Mean \pm S.E of five replications within a row followed by the different letter are significantly different at $\mathrm{p}<0.05$ 
Present study was carried out to determine physico-chemical and microbiological qualities of milk. The universal practice of wrong milking, filthy conditions of byres, polluted water supply, defective transport, warm climate, unhygienic conditions of milk shops, the lack of suitable technical and educational information causes inferior quality of milk and indigenous milk products especially in unorganized sector these are the main reasons for deterioration of milk and milk products very early.

\section{Physicochemical properties of milk sold in Banaskantha district}

Milk fat is the most valuable (economy wise) of all milk components. Milk lipids are liked for their pleasing flavour which is not duplicated in any other types of food.

The range of fat percentage in the present study was $4.81 \pm 0.18$ to $6.02 \pm 0.13$ per cent. The results in the present study were almost similar to the findings of Ramya et al., (2016), who reported $4.9 \%$ value for milk fat. Bendale et al., (2015) reported the fat contain in sample $S_{1}$ to $S_{11}$ were $2.5,3.9,2.2,3.7,1.4,3.7,3.5,3.1$, 3.8, 3.4 and 3.8 per cent, respectively.Hossain and $\operatorname{Dev}(2013)$ recorded the fat value 4.3 per cent; Singh and Pratap (2014) 6.32 per cent; Gasmalla et al., (2013); Tesfay et al., (2015); Funck et al., (2015) and Gemechu et al., (2015) observed values of fat content of fresh milk was lower than the present investigation.

Mean values of fat content of milk samples in present investigation showed significant $(\mathrm{P}<0.05)$ variation between the sample from Palanpur and Deesa and Dantiwada and Deesa whereas rest of places show no significant difference $(\mathrm{P}<0.05)$. The difference in fat content may be due to the difference in feeding pattern, breed of animal and season.

Acidity of the milk samples of present study showed the value of 0.14 to 0.16 (\% LA) as minimum and maximum. Higher acidity of milk samples were recorded from Dantiwada samples, which were higher than the reported by Bendale et al., (2015) and it was parallel to the buffalo milk sample found by Gakkhar et al., (2015). Hossain and Dev (2013) and Funck et al., (2015) asserted the values of acidity in milk sample was comparable to the present investigation. Gasmalla et al., (2013) and Jain and Shrivastava (2014) record the values of acidity in fresh milk were 0.31 and 0.14 to 0.18 , respectively.

Acidity of milk samples showed the significant variation $(\mathrm{P}<0.05)$ between Dantiwada and Deesa; Panthawada and Dantiwada in present study. The amount of acid depends on the cleanliness of production and the temperature at which milk is kept.

In the present study, minimum and maximum moisture were recorded in the Panthawada (85.64 per cent) and Dantiwada (88.41 per cent). Singh and Pratap (2014) and Gasmalla et al., (2013) recorded the value of the moisture content 82.07 is lower than the present investigation. Result indicated that no significant difference $(\mathrm{P}<0.05)$ was observed in present study between all selected places of Banaskantha district.

In the present study, the $\mathrm{pH}$ range of milk sample was 6.36 to 6.55 showed in Table 1 , which was related to the value found by Gemechu et al., (2015). Funck et al., (2015) and Tesfay et al., (2015) reported the values of $\mathrm{pH}$ in milk sample showed higher than the present investigation. Jain and Shrivastava (2014) reported the value milk $\mathrm{pH}$ in the range of 6.32 to 6.91. In present investigation, the mean value of $\mathrm{pH}$ in milk of all the places showed no significant difference $(\mathrm{P}<0.05)$. Standard according to Food Safety Standards Authority of India (FSSAI) Act 2006, Rule 2011, there is no standard for raw milk (fat, moisture, acidity, $\mathrm{pH})$. Time has come to look into the matter seriously.

\section{Microbiological analysis of milk sold in Banaskantha District}

There is a need for a better understanding of the current prevalence of bacterial pathogens in raw 
milk. This information could be used to assess the public health value of regulations banning the sale of raw milk and to educate the public concerning the probability of exposure to bacterial pathogens when consuming raw milk.

The SPC of milk samples obtained from selective places of Banaskantha district ranged from $5.97 \pm 0.01$ to $6.21 \pm 0.04 \mathrm{log} \mathrm{cfu} / \mathrm{ml}$ in present study. A similar result recorded by Hasan et al., 2015; Saxena and Rai (2013) and Woldemariam and Asres (2017). Tassew and Seifu (2011), Fadaei (2014) and Gurmessa (2014) reported the value of SPC was higher the standard plate count indicates the improper hygienic condition. Holm et al., (2004) suggested that high standard plate count can be influenced by poor storage temperature, long storage period after milking, health and hygiene of the cow, environment where milking is done as well as procedures used in cleaning and sanitizing the milking and storage equipment.

The highest coliform count was observed in milk samples of Dantiwada (3.66 \pm 0.04 log $\mathrm{cfu} / \mathrm{ml}$ ) and lowest in milk samples of Palanpur (3.23 $\pm 0.04 \mathrm{log} \mathrm{cfu} / \mathrm{ml}$ ) sample (Table 2). A comparable result recorded by Saxena and Rai (2013) and Woldemariam and Asres (2017). Fadaei (2014) reported the value of coliform count was $5.14 \mathrm{log} \mathrm{cfu} / \mathrm{ml}$. Gurmessa (2014) reported the value of coliform count was in the range of 6.4 to $6.1 \log \mathrm{cfu} / \mathrm{ml}$.

All samples were completely free from yeast and mould. It is evident from the table 2 that Yeast and mould count in experimental samples were $100 \%$ negative. A similar result recorded by Kumar et al., (2015).

As per Standard according to Food Safety Standards Authority of India (FSSAI) Act 2006, Rule 2011.

The standard plate count in all the milk samples found to be more than FSSAI only Palanpur milk sample showed the value in prescribed limit.
Highest SPC was observed in collected from Tharad sample $(6.21 \pm 0.04 \log \mathrm{cfu} / \mathrm{ml})$ which is not up to the standard.

Samples was found to be positive for coliform test, was found is greater than criteria which should be less than $10 / \mathrm{ml}$. so, it indicates faecal contamination in product might be due to poor handling, poor hygiene, contaminated water, unsanitary milking practices, and improperly washed and maintained equipment can lead to higher coliform counts in raw milk.

Yeast and mould count of the all sample were showed the negative result.

\section{References}

Bendale, V. T; Patil, C. L; Chavan R. P. And Shinde, D. N. (2015). Analysis of Milk Quality \& Adulteration in Milk Samples Collected from Thane. International Journal of Pharma and Bio Sciences. 6(4): $729-733$.

Fadaei, A. (2014).Bacteriological quality of raw cow milk in Shahrekord, Iran. Veterinary World. 7(4): 240-243.

FSSAI (2011). Food Safety and Standard Authority of India. Ministry of Health and Family Welfare, published in The Gazette of India.

Funck, G. D., Harmanns, G., Vicenzi, R., Schmidt J. T., Richard, N. and Silva, W. P. (2015). Microbiological and physicochemical characterization of the raw milk and colonial type cheese from the Northwestern frontier region of Rio Grande do Sul, Brazil. Revista doInstituto Adolfo Lutz. 74(3): 247-57.

Gakkhar, N., Bhatia, A. and Bhojak, N. (2015). Comparative study on physiochemical properties of various milk samples. International Journal of Recent Scientific Research. 6 (6): 4436-4439.

Gasmalla, M. A. A., Khadir, K. E., Musa, A., Aboshora, W. and Zhao, W. (2013). Evaluation of some physicochemical parameters of three commercial milk 
products. Pakistan Journal of Food Science. 23(2): 62-65.

Gemechu, T., Beyene, F. and Eshetu, M. (2015). Physical and chemical quality of raw cow's milk produced and marketed in shashemene Town, southern Ethiopia. Journal of food and agricultural science. 5(2):7-13.

Gurmessa, T. (2014). Physicochemical properties and Microbial Quality of raw cow's Milk in Yabello District, Borana Zone, Southern Ethiopia. M.Sc. Thesis Submitted to the School of Graduate Studies (School of Animal and Range Science) Haramaya University.

Hasan, A., Islam, A; Mahmud, M. S., Ashab Uddin, A.S.M. and Ahmed, S. (2015). Microbial analysis of raw and pasteurized milk from selected areas of Dinajpur, Bangladesh. Asian Journal of Medical and Biological Research. 1(2): 292-296

Holm, C., Mathiasen, T. and Jesperson, L. (2004). A flow cytometric technique for quantification and differentiation of bacteria in bulk tank milk. Journal of Applied Microbiology. 97(5): 935-941.

Hossain, M. B. and Dev, S. R. (2013). Physiochemical Characteristics of Various Raw Milk Samples in a Selected Dairy Plant of Bangladesh. International Journal of Engineering and Applied Sciences.1(3): 91-96.

Jain, N. and Shrivastava, S. (2014). Quality Assurance of Marketed Raw Milk in Bhopal city, MP, India. International Research Journal of Biological Sciences. 3(11): 23-27.

Kumar, V., Arora, P., and Ibrahim, M. (2015).
Studies on microbiological quality of milk and milk products sold in Allahabad city. International Journal of Applied Research. 1(9): 232-234.

Ramya, P., Babu, A. J., Reddy, E. T., Reddy, Y. R. and Rao, L. V. (2016). Analysis of various physico chemical properties of raw buffalo milk samples marketed in and around Proddatur town, YSR Kadapa district, Andhra Pradesh, India. Journal of Livestock Science. 7: 30-34.

Saxena, M. and Rai, P. (2013). Microbiological and Chemical Analysis of Raw, Pasteurized and UHT Milk During Preservation in India. International Journal of Chem Tech Research. 5(6): 2804-2809.

Singh, A. and Pratap, A. (2014).Comparison of Physicochemical Properties of Raw Milk from Indigenous and Exotic Cows at Allahabad. International Journal of Science and Research.3(8): 1566-1568.

Tassew, A. and Seifu, E. (2011). Microbial quality of raw cow's milk collected from farmers and dairy cooperatives in Bahir Dar Zuria and Mecha district, Ethiopia. Agriculture and Biology Journal of North America. 2(1): 29-33.

Tesfay, T., Kebede, A. and Seifu, E. (2015). Physico Chemical Properties of Cow Milk Produced and Marketed in Dire Dawa Town, Eastern Ethiopia. Food Science and Quality Management. 42: 56-61.

Woldemariam, H.W. and Asres, A.M. (2017). Microbial and Physicochemical Qualities of Pasteurized Milk. Journal of Food Process Technology. 8(1):1-5.

\section{How to cite this article:}

Nalwaya, S.B., B.I. Prajapati, A.R. Bariya, M.M. Goswami and Roy, S.K. 2018. Evaluation of Physico-Chemical and Microbiological Quality of Milk of Banaskantha District, India. Int.J.Curr.Microbiol.App.Sci. 7(12): 1635-1641. doi: https://doi.org/10.20546/ijcmas.2018.712.191 